\title{
The ones whogot away from Time and Loss
}

\section{A moment to reflect. By Andrea Kriz}

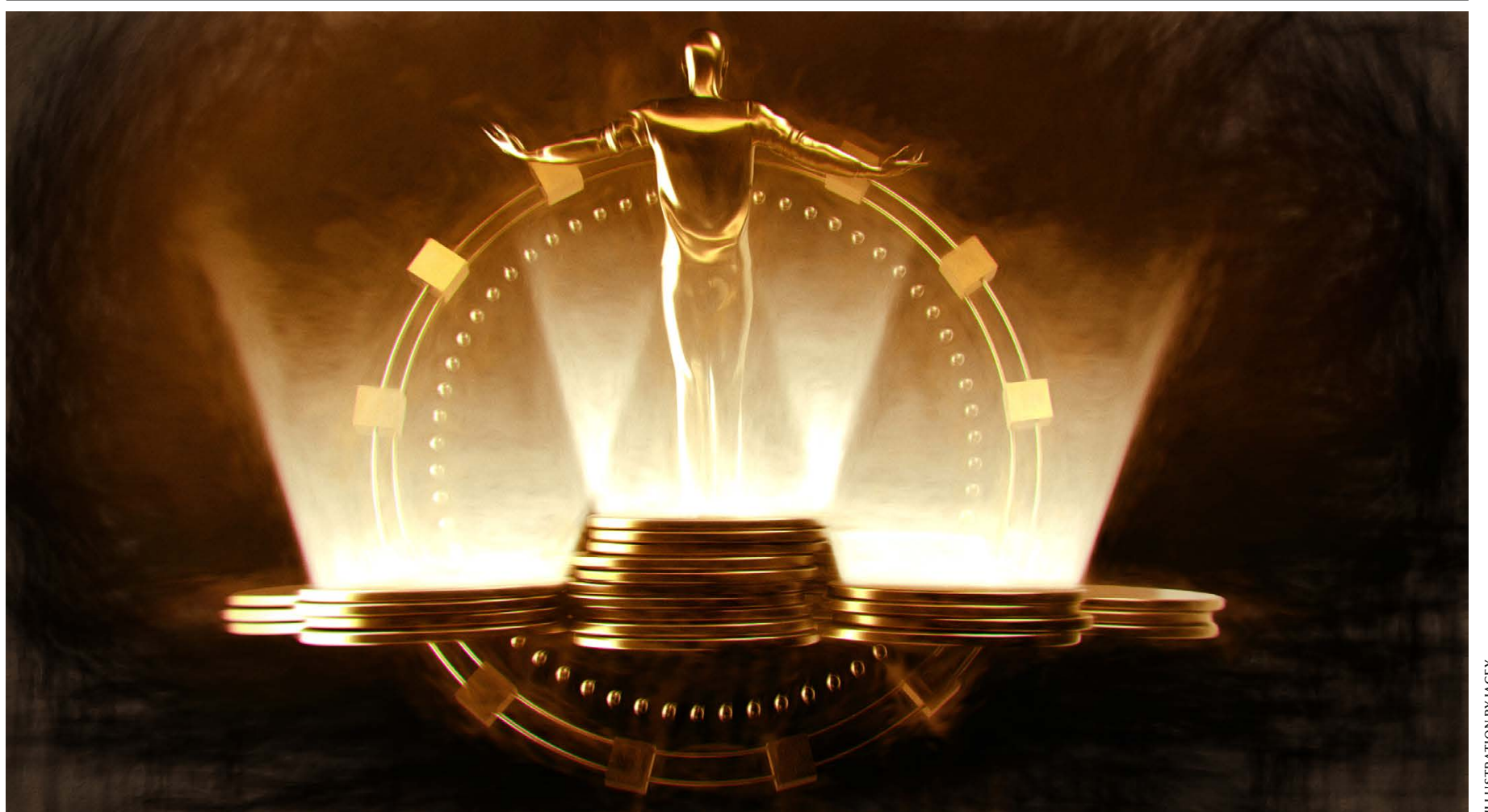

nd the winner of the 2051 Nobel Prize in Physiology or Medicine is ..."

I spat out my coffee. Kae craned out of our kitchen nook, a bowl cradled in his arms. Leaves in his hair. He'd been hard at work, experimenting on what he'd only evasively refer to as a 'basil and Nutella recipe'.

"What's wrong?"

"Work emergency."

“Want some breakfast?"

"Sorry." I pecked his cheek to hide my relief. "Be back by dinner."

I'd made it clear when we'd started dating. The downside of my job at the Department of Timeline Security and Bylaws - Time and Loss, for short - was never having a day off. The movies I'd glued myself to as a kid had conjured up glorious moral quandaries, desperadoes going back in time and killing Hitler. Us wiping a tear from our chrome-plated visors and setting the timeline right again. But as I climbed into a hover cab I couldn't afford, I saw the same story on the city dome's holoscreen that l'd dealt with nearly a hundred times before.

"I just had a eureka moment," the Nobel snatcher proclaimed. "All my postdocs looked at me - like I'd dropped in from the future. I knew immediately what experiments we had to do to make whole-organ gene editing a reality..."

Turns out people didn't want to kill Hitler. They didn't want to rewrite the script. They'd rather recast themselves in the leading role instead. In my damp office, the director's cut was more permanent, at least. Research articles I'd torn out of old journals collaged the walls. Foundations, I called them. The double helix of DNA, splicing, deep sequencing and so on. Any traveller who'd remodelled the timeline of molecular biology would
inevitablyleaveatraceinthesepapers,too.Li,my partner, had already marked up the likeliest culprits with red string.

"Here."

It took me less than an hour to spot the divergence point. A gel image. Its first lane jagged, the other half embedded in the text of a paper published years later. I stepped into our converted broom closet. While I cranked dials, $\mathrm{Li}$ crammed himself in beside me. He flipped a switch and the engine groaned; a chunk of panelling fell from the ceiling.

"When?"

"2020 should do it."

Darkness warped into the clank of a film developer. We strode through rows of lab benches, dodging around floor centrifuges and deep freezers to let ourselves into a spacious corner office. The Nobel snatcher reclined in an ergonomic chair, champagne flute in hand. 


\section{Futures}

"What took you so long?"

She was the worst of our repeat offenders. A former professor who'd hijacked her department's time machine, and therefore had the nasty habit of reappearing every time we arrested her. She'd won the Nobel prize for instantaneous sequencing, 50-colour live-cell imaging, jump portals and just about anything else you could think of.

"You're better than this," she whispered as I cuffed her. She crumpled something into my palm. "You should be chasing the ones who got away."

As the clean-up crew from Timeline Corrections popped in, I unfolded it. The first page of a research article. I scanned the author list and froze. I stuffed it into my pocket just as my phone buzzed. It was Kae. Recipe didn't work out. Sushi? Against my better judgement Ijoined Li at his usual post-work hangout instead. I stared into my bowl of rapidly congealing ramen while he barked karaoke at our table's holoscreen.

"What did she mean?" I finally asked him. "The ones who got away."

“Well. You've realized by now, haven't you? It took three months for the government to form
Time and Loss after time travel went public."

"So the Hitler in the historeels -"

"Some crazed superfan, probably. But the history sub-department's got it covered. They've got all the funding. Think about us. Basic sciences? We've got people handling Nobels and patent cases, sure, but what about everything else? The authors of a typical Nature paper change 12 times daily, I heard. Just from scientists time-scooping their competitors."

My hands shook.

“We can't keep the timeline perfect." Li burped drunkenly. "But we're doing good enough. That's what's important."

What was important? I'd told myself it was bad luck, the whole time. Back at the end of my PhD, when the project l'd been working on for five years had been scooped. Another lab just had the same idea. They'd beaten us to publication by months. Well deserved, good game, that's just how science worked, and all that. But here it was. Under a neon holoscreen, I unfolded what the Nobel snatcher had given me again. A Nature paper, and me in the first spot of the author list. Maybe this had been the original timeline. Who's to say it hadn't? My phone buzzed madly - Kae - and I swiped it to mute. In a few steps, I'd be back at the office. We always kept enough fuel in the closet for an emergency time jump.

I deserved it. And so much more.

I woke in a bed soft as clouds, beside a college sweetheart who'd broken up with me for not being enough of an 'achiever'. My ratty carpet had turned plush; the dubious smells of hazelnut and herbs into an expertly homemade quiche that, for some reason, tasted oddly cold.

"I just got a call, honey."

I hadn't even been greedy. It would be shared three ways, the original discoverer - as far as I could tell - remaining a co-recipient. The committee had been planning to give it to only one person, anyway. It would've been such a waste. I snapped on the holoscreen.

"The winner of the 2051 Nobel Prize in Physiology or Medicine is ..."

Andrea Kriz writes from Cambridge, Massachusetts. Find her other stories in Futures, Cossmass Infinities, Ahoy Comics, and her @theworldshesaw. 